\title{
TECHNIQUES OF INFORMATION SPACE MODELING IN MILITARY FIELD
}

\author{
Ruta Surovcova ${ }^{1}$, Sandra Murinska ${ }^{2}$ \\ ${ }^{1}$ Mg.soc.sc., Rezekne Academy of Technologies, Rezekne, Latvia, \\ e-mail: ruta.bernane@gmail.com \\ ${ }^{2}$ Dr.sc.comm., assistant professor, leading researcher, Rezekne Academy of \\ Technologies, Rezekne, Latvia, e-mail: sandra.murinska@rta.lv
}

\begin{abstract}
The aim of the paper is to research and analyze the features of the National Guard's image formation in the information space of Latvia. It is viewed within the framework of the study how the image of "the National Guard" and "a national guard" is constructed in the texts and how these constructs vary in the blog "Ivars Chiekurs and His Adventures" [in Latvian "Ivars Čiekurs un vina piedzivojumi"]. Eight blog posts are analyzed using discourse analysis. The criteria selected for analysis were the following: subject, attitude, comparisons, description, and action. The image of the National Guard on the blog "Ivars Chiekurs and His Adventures" is not unequivocal. On the one hand, the National Guard is a value and is seen as a panacea for any security threat. On the other hand, the National Guard is blamed for lying and maintaining myths, for not wanting to leave the comfort zone, taking the initiative and fighting to improve the training process and provision.
\end{abstract}

Keywords: image of National Guard, information environment, information flow, military discourse, National Guard.

JEL code: M10.

\section{Introduction}

Mass media create reality and give us an idea of how we see the world and perceive different realties. A person often becomes aware of a particular phenomenon only through the mass media. This is due to the way the information flow is organized.

The military field is a relatively closed environment that the public knows little about. As this environment is responsible for security, the amount of information about this field in the public space is negligible.

The speed and transparency of information has increased dramatically with the emergence of the Internet. Events, which would have remained a state secret a few years ago, are now being announced worldwide in a few minutes. Citizens can mobilize and form groups using social media in a very short period of time, without taking unnecessary risks and spending practically no financial resources. On the other hand, the government and various institutions can do very little to influence or stop such activity. Social media is changing the nature of political discourse and conflict (Myfield, 2011). This means that the flow of information from the public is very difficult to control. 
Social media is becoming a place for political and social activities around the world. If military leaders are not fully aware of these tools, they can lose influence on the development of future conflicts. An effective social media strategy can influence the outcome of military operations. The Armed Forces use photo and video footage on blogs, YouTube, and social media to create a positive self-image and highlight a negative image of an opponent (Myfield, 2011). Social media and the Internet as a whole have the ability to reach their desired audience without involving mediators. One of the great promises of the Internet is the possibility for individuals and grassroots organizations to overcome traditional media gatekeepers and government censorships to communicate directly with potential activists, specific groups, and the general public (Isa, Himelboim, 2018).

In order to understand how information flow is generated and transmitted, it is necessary to look at the concept of mass communication that reflects the impact of the information source accurately, and is particularly relevant in government communication or controlled information flow.

The term 'mass communication' came into use in the late 1930s, but its essential features were already well known and have not really changed since, even if the media themselves have become less massive in some ways (McQuail, 2010).

D. McQuail emphasizes the importance of mass communication in shaping public opinion:

The most obvious feature of the mass media is that they are designed to reach the many. Potential audiences are viewed as large aggregates of more or less anonymous consumers, and the relationship between sender and receiver is affected accordingly. The 'sender' is often the organization itself or a professional communicator (journalist, presenter, producer, entertainer, etc.) whom it employs. If not this, it is another voice of society given or sold access to media channels (advertiser, politician, preacher, advocate of a cause, etc.). The relationship is inevitably one-directional, one-sided and impersonal, and there is a social as well as a physical distance between sender and receiver. The former usually has more authority, prestige or expertise than the latter. The relationship is not only asymmetrical; it is often calculative or manipulative in intention (McQuail, 2010).

Public administration covers all aspects of public life. Accordingly, any aspect of public administration is closely linked to public relations. The aims of a democratic state literally correspond to the aims of public relations. A successful democratic government maintains mutually responsive relations with its voters based on mutual understanding (Katlips, Senters, Brūms, 2002). It is precisely the two-way communication principles that play an important role in the communication process. 
Thus the aim of the paper is to research and analyze the features of the formation of the National Guard's image in the Latvia's information space using discourse analysis. A strategy of discursive analysis helps to understand the reasons why people distribute their ideas in so many ways. These strategies analyze language critically and how it is used to discover the social influences that determine our behaviour and thoughts. Discursive analysis structures language to discover units of meaning - discourses that work independently of the intentions of speakers or writers (Pipere, 2011). Discursive analysis can be viewed as a way of reading text, focusing on the functions of language execution - looking for the orientation of the text to social action beyond understanding the meaning of the text (Pipere, 2016).

During the examination of the materials, the most striking word combinations and text fragments were selected, which mentioned the National Guard or a national guard and allowed to understand the orientation of the text towards a certain social activity and to draw conclusions about the dominant discourses. The criteria selected for analysis were the following: subject, attitude, comparisons, description, and action.

\section{Construction of National Guard's image}

The National Guard's image is partially formed by the Ministry of Defence. The Ministry's communication could be divided into controlled and uncontrolled communication. The controlled communication includes the part of the information space that is created and coordinated by the Military Public Relations Department of the Ministry of Defence.

\section{Table 1 Information channels controlled by the Ministry of Defence}

(Created by authors)

\begin{tabular}{|l|l|}
\hline 1. & Magazine “Tevijas Sargs" $(06 / 1992-12 / 2018)$ \\
\hline 2. & Page on draugiem.lv \\
\hline 3. & Twitter account since $05 / 2010$ \\
\hline 4. & Flickr account since $07 / 10 / 2010$ \\
\hline 5. & Youtube channel since $07 / 2010$ \\
\hline 6. & Facebook page since $23 / 06 / 2010$ \\
\hline 7. & Broadcast “Laiks Viriem" $(12 / 2013-01 / 2019)$ \\
\hline 8. & Broadcast “Latvijas Karavirs” (since $04 / 2014)$ \\
\hline 9. & Instagram account since $05 / 2017$ \\
\hline 10. & Press releases in different mass media \\
\hline
\end{tabular}

Press officers have been employed by the Ministry of Defence since 1992. Press releases are regularly sent to the media to keep the public informed about current developments in the defence industry. Depending on 
the importance of the information, the press release is distributed to international, national and regional media. Literature analysis also concluded that military organizations should control the flow of information to prevent the entering of unwanted and operational security information in the public space (Jonasz, 2012), whereas the aforementioned defence public relations activities are characteristic of the closed-system mindset described in the literature studies, which is aimed at getting society to act in accordance with the organization's plans. One-directional communication is typical for closed mindset (Katlips, Senters, Brūms, 2002). Media researcher D. McQuail explains that traditional mass communication was essentially onedirectional, while the new forms of communication are essentially interactive. A communication network refers to any set of interconnected points (persons or places) that enable the transmission and exchange of information between them. For the most part, mass communication is a network that connects very many receivers to one source, while new media technologies usually provide interactive connections of several different kinds (McQuail, 2010).

Feedback is one of the features characterising democratic communication that also is aware of the public interest. It is best seen in twoway communication. A striking example of this is the activity and reaction of the public. Therefore, the study looks at communication (the formation of a national guard's image, created by society), that is, communication independent of the state structures.

\section{Analysis of the blog "Ivars Chiekurs and His Adventures"}

The National Guard is actively discussed and judged in the blog "Ivars Chiekurs and His Adventures" [in Latvian "Ivars Čiekurs un vina piedzivojumi"] (hereinafter blog). The blog was launched in 2012 and has 233 posts since then. Eight posts are related to the National Guard and mention the words "the National Guard" and "a national guard". Posts about the National Guard and national guards were made between March 25, 2015 and October 22, 2017. The blog focuses on problems faced by national guards and the National Guard in general. These are controversial publications that have caused both public acceptance and condemnation (Ivars Čiekurs un vina piedzivojumi). The first post, entitled "X Hour - Escalation (Part II)", featuring the words "the National Guard" and "a national guard", was posted on March 25,2015 . The article is sarcastic and depicts a state of war declared in the country. The image of a national guard and his role in national defense are ridiculed by referring to the unpreparedness of national guards, both in terms of taking responsibility that is indicated with the words "national guards' fooling around does not inspire" in the text (blog "Ivars Čiekurs un 
vina piedzivojumi", 25.03.2015.) and attendance of the training: "After that news, communications broke down; Aina's desperate crying in the handset and changing the switches turned out to be fruitless. Later investigation of the reports will lead to the conclusion that a national guard Liepins had missed the aircraft recognition training because of his cousin's silver wedding anniversary" (blog "Ivars Čiekurs un vina piedzīvojumi", 25.03.2015.)

As is known, the National Guard's service is based on a voluntary basis and takes place during leisure time, so it is possible that a national guard is missing the training or unable to attend it. In certain situations, a national guard is also not entitled to take responsibility for the decision. The article also mentions wastefulness and wastage "when he inspects the shelves and concludes that the shelf, which, according to the layout of the room, has to be stocked with National Guard boots, is empty" (blog "Ivars Čiekurs un vina piedzivojumi", 25.03.2015.). The blame here is not on the National Guard itself, but on the Latvian Club of Generals. The post called "Kokmuiza beer Latvia's shame, Valmiermuiza's disgrace" (blog "Ivars Čiekurs un vina piedzivojumi", 04.11.2015.,) mentions the foundation Zemessargam.lv, which is the initiator of the donation campaign "Helping the National Guards, You Help Yourself", where people are invited to donate to the national guards for the purchase of the necessary equipment (foundation Zemessargam.lv). In this case, the National Guard is likened to traditional values important to Latvians, accusing "Valmiermuizas alus" and its manager, Aigars Rungis, of showig off with Latvian symbols and festivites, but not being on the Zemessargam.lv donation list. Accordingly, we can conclude that the National Guard and the service in the National Guard have value for Latvians. In the post of September 13, 2016, entitled "Let's Dig in the National Guard" (blog "Ivars Čiekurs un vina piedzivvojumi", 13.09.2015.) the equipment available to the National Guard - the "Swedish gifts" - is criticized and compared with the superior equipment available to Estonian and Lithuanian national guards. Backpacks, patrol bags and accoutrement are compared. It is also emphasized that the equipment and its technical state do not correspond to the role and tasks assigned to the National Guard in the defense concept "paramilitary activity" and that "the public is brutally lied about the National Guard's capabilities, its strengthening over the years and the level of equipment" (blog "Ivars Čiekurs un vina piedzīvojumi", 13.09.2015.). Using blatant remarks, the author of the post points out that the National Guard has been neglected and it does not receive the necessary attention, but in the event of a crisis, "taking into account the territorial aspect, it will be up to the individual National Guard units to carry the initial heaviness of war - who will be thrown first at the potential threat if not the national guards hastily scanned from the nearest battalion" (blog "Ivars Čiekurs un viña 
piedzivojumi", 13.09.2015.). Correspondingly, the activities of national guards and their contribution to national defense are altruistic, noting that they not only spend their time in training, but also invest their resources in the purchase of equipment. Despite the author's critical remarks about the equipment available to the National Guard, the National Guard as an organization is not blamed for the current situation. It can be concluded that the National Guard is given the role of a stepchild, entrusted with a superhuman task, but national guards are treated as a puppets that perform their duties in a selfless and altruistic manner. In the post "Let's Dig in the National Guard: 800 Cubic Meters" (blog "Ivars Čiekurs un viña piedzivvojumi", 10.10.2016.), medical problems of the National Guard are discussed. The National Guard's level of readiness to fight against the opponent is ridiculed, saying "we are ready to sacrifice a few thousand volunteers symbolically". The author of the article analyzes the medpacks used by the National Guard - "issued rags" that "ended up being sterile about 20 years ago" (blog "Ivars Čiekurs un viṇa piedzīvojumi”, 10.10.2016.). He also talks about the National Guard's reluctance to adopt modern practices to apply the tourniquet, saying that "it is actually forbidden to teach the use of the tourniquet - so that the stupid guards do not harm each other and no authority in charge has to give up the annual bonus" (blog "Ivars Čiekurs un vina piedzivojumi", 10.10.2016.). The author criticizes the medical training of national guards, the contents of the unit's medpacks, and the lack of evacuation transport. The individual provision of a national guard's medpack is described as being between World War I and World War II. The author reiterates that "the National Guard will be sent first against enemy's regular forces" (blog "Ivars Čiekurs un viña piedzīvojumi", 10.10.2016.), therefore, in view of the problems described, the role played by the National Guard in the concept of defense is called criminal, negligent and filthy. The post also presents a national guard in a comparatively better way, pointing to the initiative to supplement both the contents of the medical bag and the knowledge of oneself on his/her own financial means. With regard to evacuation transport and the transportation of the wounded, a comparison is made of "a national guard is made of asbestos and patriotism and therefore no bodily needs are anticipated" (blog "Ivars Čiekurs un viṇa piedzivojumi", 10.10.2016.). In this post, the National Guard is criticized for not wanting to leave the comfort zone and improve the training process, as well as to diversify it with current practices in today's society. A national guard, on the other hand, is undervalued because he/she can obtain far beyond what the training program has to offer and is praised for self-organization abilities and initiative. The issue of armored vests and armored vehicles available to the National Guard is being raised on the post "Let's Dig in the National Guard: Armor and Turtle" published on October 16, 2016 (blog "Ivars Čiekurs un 
vina piedzīvojumi", 16.10.2016.). "National guards are basically running around wearing fragmentation vests in a Norwegian camouflage"; it is mentioned once again that this gift is "relatively fresh and certainly better than nothing", while the National Guard's evacuation transport is "not even mentioned". The author heavily mentions that "there is a tarpaulin between the national guard's back and the bullet" and describes the situation as "the enemy in the media laughs at the national guards' unit killed in trucks," ironically called "a sprat unit". National guards seem to be doomed in this post, while the National Guard as an organization and its leadership do not act and accept the possible future and its consequences. The post "Let's Dig in the National Guard: The End" (blog "Ivars Čiekurs un vina piedzivvojumi", 26.11.2016.), published on November 26, 2016, explains how the current situation in the National Guard is commensurate with the tasks assigned and why the blog's findings are so different from official statements of the defense industry's authorities. In this case, the National Guard is associated with the words "keeping the myth", "partially supplied", "brutally underrepresented", "purposefully continuing to lie", "numerically disfigured and infamously equipped paramilitary formation", "misleading the public", "myth about the National Guard as Latvia's unique panacea for any security threat " (blog "Ivars Čiekurs un vina piedzivojumi", 26.11.2016.). At the same time, when talking about national guards, it is said that "national guards were praised by every non-lazy official," "the scandalous, 8,000 national guards are certainly not true", "national guards equip themselves at their own expense to the extent possible, seeking to achieve adequate combat capabilities" (blog "Ivars Čiekurs un vina piedzìvojumi", 26.11.2016.). However, there are things that cannot be solved on their own, such as medpacks, armored vehicles, and armored vests. It is also frankly discussed that "most national guards do something different on a daily basis", therefore "they attend training irregularly" and "abilities and knowledge differ" (blog "Ivars Čiekurs un viṇa piedzīvojumi", 26.11.2016.). The National Guard is associated with purposeful lying and maintaining myths about both the number of guards and level of equipment, while being a panacea for any security threat at the same time. National guards invest their personal financial resources as much as possible to purchase the equipment, but there are issues where they are powerless. The National Guard's service is based on a voluntary basis, so each person evaluates how much time he/she is ready to spend at the National Guard and the training process, which leads to different levels of ability and knowledge. In the post entitled "Parquet Military Service" (blog "Ivars Čiekurs un vina piedzìvojumi", 08.09.2017.), the author analyzes the compulsory military service, saying that "national guards are able to acquire the basic military training in a much shorter time" than soldiers. The National Guard mentions the creation of a new battalion. 
The author calls into question the fact that all the surrounding battalions have reached the required number of personnel, thus calling out the creation of a new battalion unjustified. The authorities of the defense industry are accused of "playing with the number of active national guards" in the post "Someone is Lying: Part 2 - Number of National Guards" (blog "Ivars Čiekurs un viña piedzīvojumi", 22.10.2017.). Although a national guard is not always flatteringly labeled as a puppet in the blog "Ivars Chiekurs and His Adventures", the image of a national guard is constructed in a positive light and discourse is supportive. A national guard is investing his/her time and resources in strengthening the national defense, is commendable for initiative and self-organization abilities; he/she is patriotic, selfless and altruistic as well. Also, a national guard cannot be called a puppet in the hands of the defense sector because he/she serves on a voluntary basis, so it is up to the individual whether to comply with the system.

\section{Conclusions and suggestions}

The image of the National Guard on the blog "Ivars Chiekurs and His Adventures" is not unequivocal. On the one hand, the National Guard is a value and is seen as a panacea for any security threat. On the other hand, the National Guard is blamed for lying and maintaining myths, for not wanting to leave the comfort zone, taking the initiative and fighting to improve the training process and provision. The National Guard is also portrayed as a victim, not a culprit, because there is senior management whose decisions are not always influenced by the National Guard. Thus, it can be concluded that a negative discourse prevails in this case.

It is necessary to update the communication of the defense sector with the public and the significance of this communication in the information war era. Communication must become one of the priorities of the defense sector.

\section{References}

1. Corner, J., Parry, K. (2017). The media and the military: editorial. Media, Culture and Society, Vol.39(1), pp. 3-10. Retrieved: 09.05.2019. Retrieved from https://journals.sagepub.com/doi/pdf/10.1177/0163443716673897

2. Isa, D., Himelboim, I. (2018). A Social Networks Approach to Online Social Movement: Social Mediators and Mediated Content in \#FreeAJStaff Twitter Network. Social Media + Society. January-March, p. 1-14.

3. Ivars Čiekurs un vina piedzīvojumi, emuārs. Sadaḷa: Emuāra arhīvs. Retrieved from http://ciekurs.blogspot.com/

4. Jonasz, A. (2012). Social Media: Some Things to Consider Before Creating an Online Presence. The Army Medical Department Journal, January-March 2012, pp. 37-46.

5. Katlips, S. M., Senters A. H., Brūms G. M. (2002). Sabiedriskās attiecības. Rīgā: Izdevniecība "Avots" 
6. Latvijas Republikas Zemessardze, mājaslapa. Sadaḷa: Par mums Vēsture. Retrieved: 10.04.2019. Available on: https://www.zs.mil.lv/lv/par-mums/vesture

7. Latvijas Republikas Zemessardze b, mājaslapa. Sadaḷa: Par Zemessardzi Struktūra. Retrieved: 10.05.2019. Retrieved from http://www.mrcc.lv/lv/ZS2/ Par\%20Mums/Struktura.aspx

8. Latvijas Republikas Zemessardzes likums (2010). Latvijas Republikas Saeimas likums. Latvijas Vēstnesis, Nr. 82 (4274), 26.05.2010. Retrieved: 19.05.2019. Retrieved from https://likumi.lv/doc.php?id=210634

9. Latvijas sabiedriskie mediji, Latvijas Televīzijas un Latvijas Radio portāls. Sadal̦a: Raksts, Zinas, Latvija. Retrieved: 09.04.2019. Retrieved from https://www.lsm.lv/raksts/zinas/latvija/komandieris-zemessargu-skaits-turpinapalielinatiesun-sogad-ir-rekordliels.a299163/

10. McQuail, D. (2010). McQuail's Mass Communication Theory. $6^{\text {th }}$ edition. New Delhi: Sage Publications.

11. Myfield, T. D. (2011). A Commander's Strategy for Social Media. Joint Force Quarterly, issue 60, 1st quater 2011, 79-83. Retrieved from https://apps.dtic.mil/dtic/tr/fulltext/u2/a535374.pdf

12. Olupe, E. (2012). Komunikācija publiskajā telpā: noklusēšanu determinējošie faktori. Scientific Journal of Riga Technical University, Vol.20, pp. 46-52.

13. Pipere, A. (2011). Datu analīze kvalitatīvā pētījumā. Mārtinsone K., Pipere A. (zinātniskās redaktores). Ievads pētniecībā: stratēǵijas, dizaini, metodes". Rīga: SIA "Izdevniecība RaKA". 